\title{
Pasco Basin \\ Stratigraphic Nomenclature
}

R. K. Ledgerwood

C. W. Myers

R. W. Cross

May 1978

Prepared for the United States

Department of Energy

Under Contract EY-77-C-06-1030

\section{Rockwell International}

Atomics International Division

Rockwell Hanford Operations

Richland, WA 99352 


\section{DISCLAIMER}

This report was prepared as an account of work sponsored by an agency of the United States Government. Neither the United States Government nor any agency Thereof, nor any of their employees, makes any warranty, express or implied, or assumes any legal liability or responsibility for the accuracy, completeness, or usefulness of any information, apparatus, product, or process disclosed, or represents that its use would not infringe privately owned rights. Reference herein to any specific commercial product, process, or service by trade name, trademark, manufacturer, or otherwise does not necessarily constitute or imply its endorsement, recommendation, or favoring by the United States Government or any agency thereof. The views and opinions of authors expressed herein do not necessarily state or reflect those of the United States Government or any agency thereof. 


\section{DISCLAIMER}

Portions of this document may be illegible in electronic image products. Images are produced from the best available original document. 


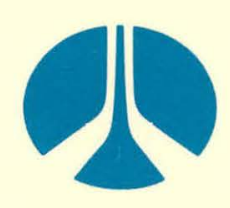

\title{
Rockwell International
}

\author{
Atomics International Division \\ Rockwell Hanford Operations \\ Richland, WA 99352
}

\author{
PREPARED FOR THE UNITED STATES DEPARTMENT OF ENERGY \\ UNDER CONTRACT EY-77-C-06-1030
}

\section{PRELIMINARY REPORT}

This Report contains information of a preliminary nature. It is subject to revision or correction and therefore does not represent a final Report. It was prepared primarily for internal use within The Rockwell Hanford Operations. Any expressed views and opinions are those of the Author and not necessarily of the Company.

\section{NOTICE}

This Report was prepared as an account of work sponsored by the United States Government. Neither the United States nor the United States Department of Energy, nor any of their Employees, nor any of their Contractors, Subcontractors, or their Employees, makes any warranty, express or implied, or assumes any legal liability or responsibility for the accuracy, completeness, or usetulness of any information, apparatus, product or process disclosed, or represents that its use would not infringe privately owned rights. 
PASCO BASIN STRATIGRAPHIC NOMENCLATURE

R. K. Ledgerwood

C. W. Myers

R. W. Cross

Waste Isolation Program Basalt Geosciences Unit Research Department Research and Engineering

May 4, 1978

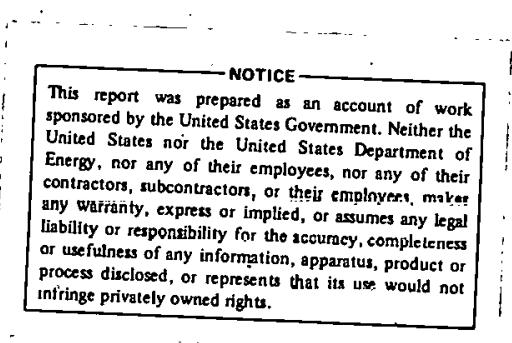

Rockwell International Atomics International Division Rockwell Hanford Operations Richland, Washington 99352 
The enclosed chart represents the stratigraphic nomenclature used by the Waste Isolation Program in the Pasco Basin, Washington as of May 4, 1978.

An attempt has been made to use currently accepted regional nomenclature and symbols for stratigraphic units of member rank. (1-6) Informal nomenclature is used for stratigraphic units of flow and bed rank; this usage is consistent with the code of Stratigraphic Nomenclature, Article 8, Remark (a).. (7)

Note that the first letter of the symbol for members indicates the system and the second letter indicates the member name -- not the formation name. For example, Tp indicates Tertiary System, Pomona Basalt Member. This method permits greater flexibility for avoiding long, complex letter symbols on detailed maps and cross sections showing units below member rank.

It is expected that this terminology will evolve, undergoing changes as additional work is conducted in the Pasco Basin and across the columbia River Plateau.

\section{REFERENCES}

1. Research and Engineering Division, Preliminary Feasibility Study on Storage of Radioaclive Wastes in Columbla kiver Basalts, ARH-ST-137, Atlantic Richfield Hanford Company, Richland, Washington (November 1, 1976). 
2. R. S. Coe, S. Bogue, and C. W. Myers, Paleomagnetism of the Grande Ronde (Lower Yakima) Basalt Exposed at Sentinel Gap; Potential Use for Stratigraphic Correlation, RHO-BWIST-2, Rockwell Hanford Operations, Richland, Washington (January 1978).

3. D. A. Swanson, et al., "Reconnaissance Geologic Map of the Columbia River Group, Pullman and Walla Walla Quadrangles, Southeast Washington and Adjacent Idaho," U. S. Geological Survey Open File Report 77-100 (1977).

4. T. L. Taylor, The Basalt Stratigraphy and Structure of the Saddle Mountains of South-Central Washington, M. S. Thesis, Washington State University, Pullman, Washington (1976).

5. Washington Public Power Supply System, WPPSS Nuclear Projects No. 1 and 4, Preliminary Safety Analysis Report, Amendment 23, Washington Public Power Supply System, Richland, Washington (1977).

6. N. D. Watkins and A. K. Baksi, "Magnetostratigraphy and Oroclinal Folding of the Columbia River, Steens and Owyhee Basalts in Oregon, Washington, and Idaho," American Journal of Science, 274, 148-189 (February 1974).

7. American Commission on Stratigraphic Nomenclature, Code of Stratigraphic Nomenclature, The American Association of Petroleum Geologists, Inc., Tulsa, Oklahoma (1970).

\section{DISTRIBUTION}

Number of Copies

1

CENTRAL WASHINGTON UNIVERSITY

Department of Geology

J. F. T. Agapito

Colorado School of Mines

Fenix \& Seisson, Inc. (2)

Geoscience Research Consultants (2)

Lawronce Berkeley Laboratory (2)

F. L. Parker

I. Remson

W. K. Summers and Associates

U. S. Geological Survey-Water Resources

U. S. Geological Survey-Western Division

Iniversity of Minnesota

Washington State Department of Ecology

Washington State Department of Natural Resources (2)

Washington State University

A. C. Waters 
Number of Copies

1

1

1

1

1

3

$12^{\circ}$

3

1

1

1
EASTERN WASHINGTON UNIVERSITY

Department of Geology

IDAHO BUREAU OF MINES AND GEOLOGY

M. Miller

OREGON STATE DEPARTMENT OF GEOLOGY AND MINERALOGY

V. C. Newton

U. S. ARMY CORPS OF ENGINEERS

Walla Walla District Geologist

U. S. BUREAU OF RECLAMATION

Columbia Basin Project Geologist

U. S. DEPARTMENT OF ENERGY-HEADQUARTERS
M. W. Frei
C. A. Heath
D. L. Vieth

U. S. DEPARTMENT OF ENERGY-RICHLAND OPERATIONS OFFICE
J. W. Anttonen
D. J. Squires (4)
T. A. Dauman
D. J. Elgurt
R. B. Goranson
F. R. Standerter
M. W. 'l'ierrlldl
A. G. Lassila
P. S. Van Loan

U. S. NUCLEAR REGULATORY COMMISSION
W. P. Bishop
J. C.. Malaro
E. P. Regnier

IN IVERSITY OF IDNHO

Department of Geology

UNIVERSITY OF WASHINGTON

Department of Geology

WASHINGTON PUBLIC POWER SUPPLY SYSTEM

D. D. Tillson 
Number of Copies

87
ROCKWELL HANFORD OPERATIONS

H. Babad

R. L. Biggerstaff

J.A. Caggiano

R. W. Cross

T. A. Curran

R. A. Deju

H. B. Dietz

G. C. Evans

K. R. Fecht

R. E. Gephart

R. J. Gimera

M. G. Jones

A. D. Krug
R. D. Landon

R. K. Ledgerwood

J. T. Lillie

P. E. Long

J. T. Meyer

C. W. Myers

S. M. Price

W. H. Price

B. H. Richard

R. T. Wilde

Waste Isolation Program Library (30)

Document Services (4) 


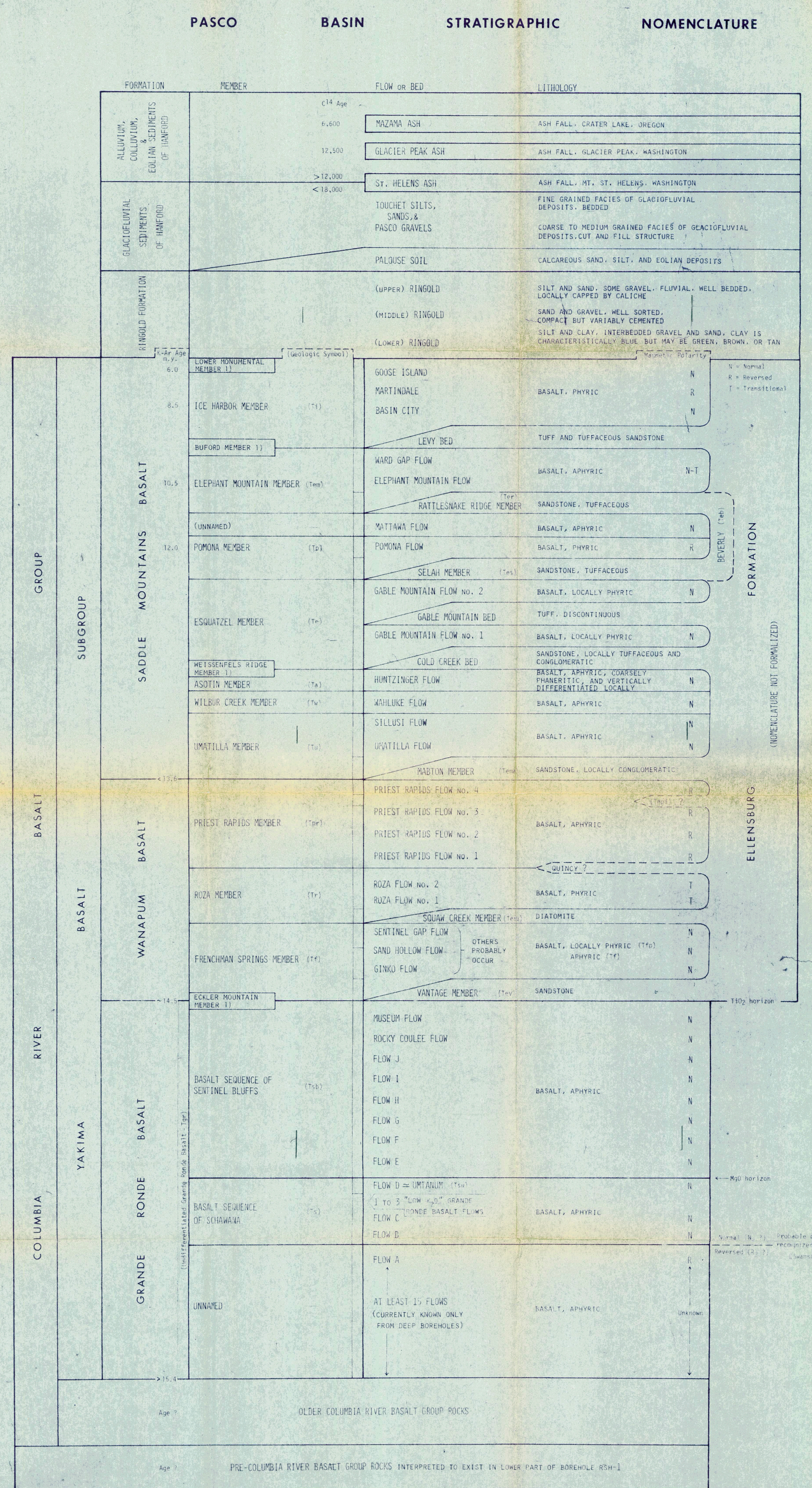

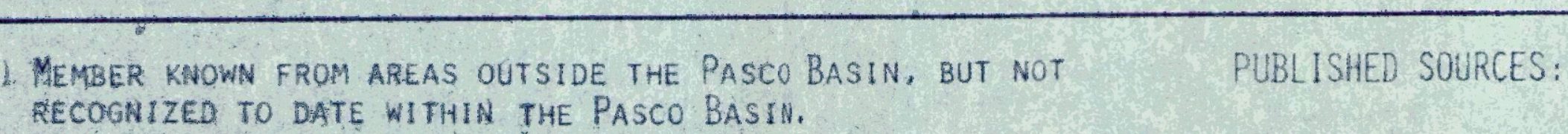

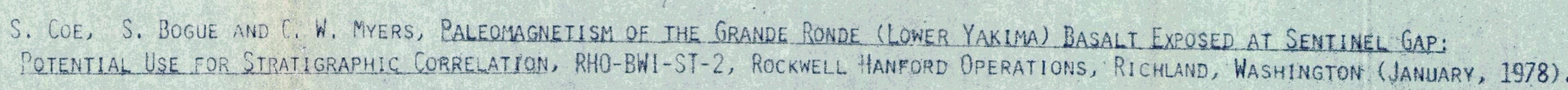

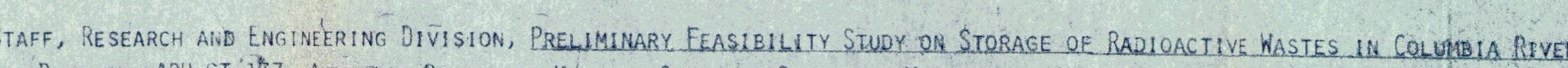

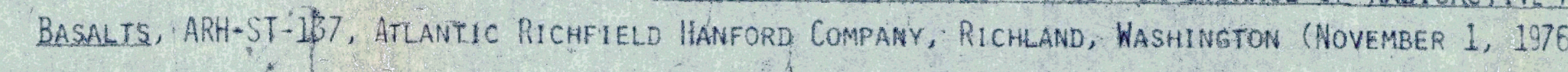

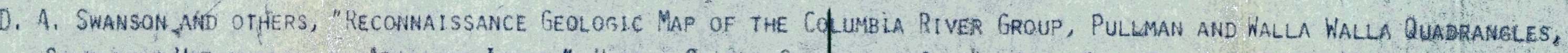

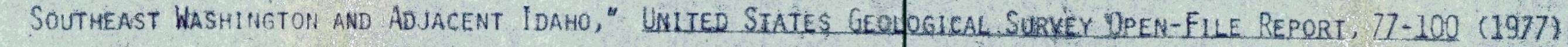

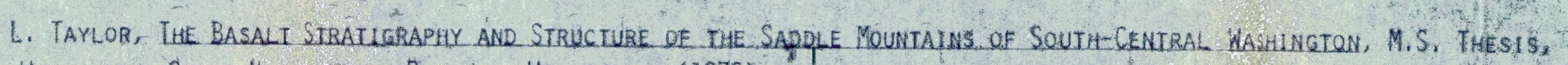

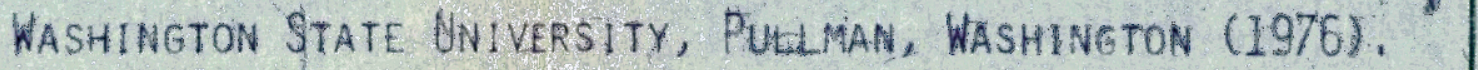

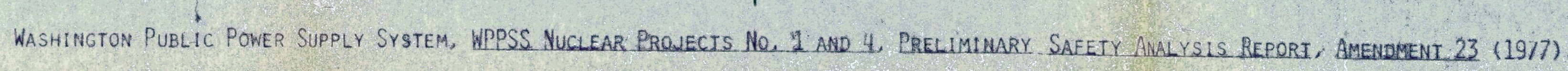

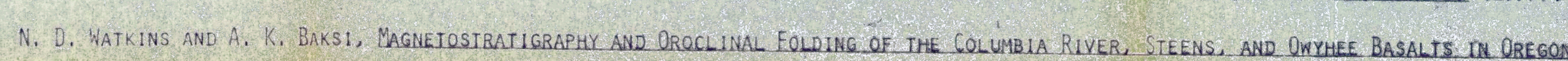
Wastivg ton

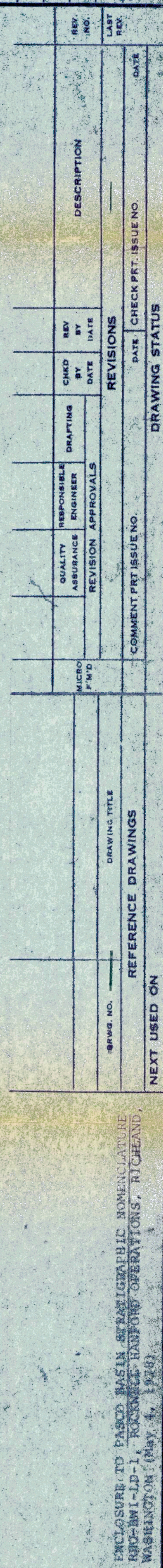

